\title{
The Impact of Property Assessment Standards on Property Tax Burden:
}

\section{An Examination of Systematic Bias in a Market Value versus a Non-Market Value Assessment Standard}

\author{
Seth B. Payton \\ School of Public and Environmental Affairs \\ and \\ Indiana University Public Policy Institute \\ Indiana University-Purdue University Indianapolis \\ Indianapolis, IN46202 \\ sbpayton@iupui.edu \\ 317-278-4898 \\ November 2010
}

2012

Public Finance Review, 40(5), 584-613. doi:10.1177/1091142111431254 


\title{
The Impact of Property Assessment Standards on Property Tax Burden: An Examination of Systematic Bias in a Market Value versus a Non-Market Value Assessment Standard
}

\begin{abstract}
Property tax is a tax on estimated values rather than transactions - an important distinction from other taxes. Another distinction is that each state develops its own system for administering the property tax, including how properties are assessed. The consensus among scholars is that current market value assessment is the standard for achieving the most fair and equitable property tax burden. This study compares two disparate assessment standards in one urban county, analyzing potential determinants of systematic bias. The findings indicate that less systematic bias exists under the market value standard, but that the overall equity is only marginally better horizontally and tended toward a more regressive tax structure. A market value assessment standard may mitigate the inherent inequity (i.e., systematic bias) in a non-market value system. However, the inequities in the market value system, which may be less predictable, still must be monitored and addressed.
\end{abstract}

Keywords: Property Tax Assessment, Sales Ratio, Local Government

JEL Classifications: H11, H71, H83 


\section{Introduction}

Scholars generally contend that real property taxes are an appropriate mechanism for funding the provision of local government services (Slemrod 1995; Fisher 1996; Oates 1999, 2000; Mikesell 2004).However, property taxes typically are not viewed favorably by the general public or political officials (U.S. Advisory Commission on Intergovernmental Relations 1989; Cole \& Kincaid 2006; Chamberlain 2007).Much of the debate surrounding the use of property tax is because of its high visibility and the lack of assurance that it can be administered fairly (Seligman 1985).Taxpayers may not be confident that they equally share in the cost of local public services and that those costs are connected to their relative abilities to pay.

The most obvious distinction between property tax and other taxes is the determination of its base. Property taxes are based on estimates and not transactions, which inherently leads to perceived and sometimes actual disparities in tax burdens. The base of the property tax is established by state specific assessment processes and standards. Statutory, administrative, and judicial parameters of property tax assessment and administration in the United States vary by state (Chicone and Geirtz 1988).Constitutional and organizational (e.g., International Association of Assessing Officers [IAAO]) tax standards mandate that the process of a true ad valorem tax (i.e., a tax proportionally levied on the value of the base) accurately represents property wealth so that the tax burden is fairly and equitably distributed. Most public finance scholars and assessing professionals agree that property wealth is most equitably and fairly determined through a full market value assessment standard. Under such a system, the goal is for assessed values to reflect market values as they change over time. That is, the system should have a process in place that accurately estimates values (property wealth) to fairly and equitably tax citizens.

Several studies have shown that deviations from the full market value, such as fractional assessment and acquisition value assessment, lead to inequitable tax burdens (Shannon 1969; Geraci and Plourde 1976; Geraci 1977; Bowman and Mikesell 1978; Bowman and Butcher 1986; O’Sullivan, Sexton, and Sheffrin 1994; Sexton, Sheffrin, and O’Sullivan 1999; Sjoquist and Pandey 2001).An inequitable tax burden among residents and businesses creates an unfair tax system that potentially affects 
a governmental unit's ability to raise revenue. Inequitable tax burdens also may create economic distortions within and among taxing jurisdictions.

In Indiana, the assessment standard has changed from non-market value assessment to full market value assessment. While unique, Indiana’s previous non-market value assessment standard provides a base from which to judge market value assessment (Smith 2002; Mikesell 2004). ${ }^{1}$ Within a quasiexperimental setting, this analysis examines the systematic assessment bias of two disparate property tax assessment standards; market value and non-market value. Specifically, potential determinants of systematic assessment bias are estimated and comparisons are made between a standard that is presumably less fair (i.e., non-market value assessment) than a version of the prescribed standard (i.e., market value assessment).

The analytical framework of this study is a modification of an older theoretical theme.The empirical approach taken in this analysis is different than the approach taken in some of the previous literature on property tax assessment. Many studies on the subject examine the disparities in assessment based solely on uniformity among jurisdictions (Almy 1977; Geraci 1977; Bowman and Mikesell 1978, Lowery 1982; Bowman and Butcher 1986; Ross 2011).This study examines disparities in assessment based on systematic bias that may lead to lack of uniformity within a single, primarily urban, county.

While this analysis is a case study of one urban county and should be interpreted cautiously, the results illuminate at least two important points about property tax standards. First, property tax assessment systems that diverge further from a market value standard can lead to inequities in a systematic way. Indiana’s non-market valuation standard was unique. However, the analysis presented here offers an example (similar to studies that examine acquisition value assessment) of how a system that calculatedly drives a wedge between market value and the property tax base systematically can lead to inequitable tax burden. Similar studies typically focus on the implementation of one type of valuation standard (e.g., acquisition value in California or Georgia). This study compares the implementation of two valuation standards in a county that was part of a statewide transition from a non-market value standard to a market value standard. Second, the results illustrate the importance of monitoring and evaluating 
assessment administration even within a system that is closer to a prescribed, less systematically biased ${ }^{2}$, market value standard.

The results from the analysis of Marion County, Indiana show that a non-market value assessment system is not only legally inferior because of the inability to objectively verify the quality of assessments, but that a much larger percentage of the variation in assessment-sales ratios among properties assessed under that standard may be explained by determinants of systematic bias. That is, more of the assessment error is built into the assessment process systematically under the non-market value standard. However, the resulting lower percentage of variation systematically explained by the market-value system did not lead to large global changes in vertical and horizontal equity. Horizontal equity only marginally improved and a common measure of vertical equity showed greater tendency toward a regressive tax burden under the market value assessment. These findings shed light on a complex policy issue in a state that attempted to reform the assessment process to be fairer. With the exception of two assessing jurisdictions (i.e., townships) in the study area, the uniformity of assessmentsales ratios did not change substantially, but the ability to understand the variations in the level of assessment did. Even still, the market valuation standard prevails as the better assessment system in terms of reduction in systematic bias associated with multiple property and location characteristics.

\section{Background: Property Tax Assessment Standards in Marion County, Indiana}

Major changes occurred in the Indiana assessment process in 2002 as a result of court-ordered reform. Specifically, a 1998 Indiana Supreme Court ruling in State Board of Tax Commissioners v. Town of St. John (1998) and subsequent rulings resulted in comprehensive changes to how the property tax base is assessed in Indiana. In 2002, the Indiana assessment standard changed from non-market valuation to one effectively based on market value for single-family residential properties. Prior to 2002, the standard for the assessment of real property in Indiana was defined in the Indiana Real Property Appraisal Manual (also known as Regulation 17) and mass reassessments were updated according to state rules. Land and 
improvements were assessed separately. ${ }^{3}$ Land value was determined by a land value commission. Improvements on single-family parcels were established using a state-determined formula-based cost method. The true tax value of improvements was estimated using cost tables minus depreciation. Statecirculated rules were used to depreciate improvements by age and physical condition (Bennett and Stullich 1992). Broadly, the cost method for improvements was based on the reproduction of a home under the rule of state-based guidelines.

The court found that the old system was in direct violation of Article 10, Section 1 of the Indiana Constitution, "the General Assembly shall provide, by law, for a uniform and equal rate of property assessment and taxation and shall prescribe regulations to secure a just valuation for all property, both real and personal." The Indiana Constitution also declares that the state must have, "a system of assessment and taxation characterized by uniformity, equality, and just valuation based on property wealth.” The old valuation standard made it extremely difficult for property owners to understand whether or not their assessment was fair or equitable because there was no linkage between true tax value and another transparent value, like market value. There was no direct linkage to property wealth.

Beginning in 2002, full market value became the Indiana assessment standard. The 2002 standard implemented in Marion County for single-family residential properties began with an estimate of replacement costs less depreciation. Those estimates were compared to prices of nearby, recently sold, properties (i.e., price comparisons). The price comparisons were used to make necessary assessed value adjustments, attempting to tie assessed values directly to property wealth.

The implied purpose for changing to a system in which assessed values are more transparent was that property assessments would be fairer and more equitable. The new Indiana assessment standard is defined as, “[the property's] current use, as reflected by the utility received by the owner or a similar user, from the property” (DLGF 2000: 8). The state’s assessment rules indicate that “true tax values” (i.e., broadly referred to as gross assessed value) can be compared to the sales price as an "objectively verifiable” measure (DLGF 2000: 20). That is, the true tax value should equal or approximate market value of single-family residential properties. 


\section{Review of Relevant Literature}

Previous literature focuses on uniformity as a measure of performance. The unit of analysis in those studies is typically counties, which is the most common level of government responsible for the primary task of assessing property (IAAO 1999). The coefficient of dispersion often has been used to measure uniformity. The coefficient of dispersion is a nonparametric measure of the absolute average percentage deviation of the assessment-sales ratios from the jurisdictional median assessment-sales ratio. Those studies serve their intended purpose, which is to empirically determine whether or not the variation among jurisdictional coefficients of dispersion is related to assessor characteristics (e.g., appointed or elected) and administrative infrastructure (e.g., use of tax maps), holding other potential influences constant (e.g., market forces and demographics).

Bowman and Mikesell (1990) provide an insightful review of 40 years of literature on the subject. They explain that uniformity matters because it is based on the principle of equity in taxation described by Musgrave and Musgrave (1989). That principle posits that people with the same capacity to pay should be equally taxed. Bowman and Mikesell (1990) explain that the relevant test is not level of assessment (i.e., assessment-sales ratio), but whether or not there are barriers to assessment uniformity. In those studies, it does not matter whether or not a property is valued correctly or whether or not certain factors are related to over- or under-assessment. Their test is whether or not the characteristics of assessment administration are significantly related to variation in jurisdictional assessment equity of similar properties.

This study examines the relationship between relevant factors and over- or under-assessment at the property level by comparing two different standards of assessment. For the purposes of this study, identifying bias implies that the focus is on the magnitude of over- and under-assessment. The purpose of identifying systematic bias is to analyze whether or not potential influences on the quality of assessment for a certain type of residential property is systematically a result of the standard used to value the property. More directly, how does the assessment standard affect tax burden? 
One may presume that the non-market value assessment system is more likely to have stronger systematic biases than a market-value based system. Under the former method, adherence to the formula is the rule with no reference to market value. Under the latter, achieving equality between assessed value and market value is the goal. The results of the analysis may be used to understand the context in which properties' tax burden is based on the assessment standard used.

Some studies have tested potential influences that may systematically affect assessment ratios (Berry and Bednarz 1975; Lowery 1982; Ihlanfeldt and Jackson 1982; Haurin 1988; Goolsby 1997; Strauss and Strauss 2004; Ross 2011). Lowery (1982) modeled several factors hypothesized to affect the level of assessment (i.e., assessment-sales ratio). Lowery’s use of assessment level (i.e., Assessed Value/Sale Price) as a dependent variable was a result of data availability, not a deliberate focus on systematic bias. The purpose of the Lowery (1982) study was based on continuing efforts to determine if assessor characteristics and administrative infrastructure affected the uniformity of assessment. Similarly, Ross (2011) used the level of assessment as the dependent variable to estimate the relationship between potential political pressures on assessors and tax burden.

Like Berry and Bednarz (1975) and Goolsby (1997), this study is less focused on potential political cue-taking by assessors and more on systematic over- and under-assessment of certain property, neighborhood, and location characteristics. This study also compares results of two distinct assessment standards. Variations of assessment-sales ratios may be the result of three broad influences (Berry \& Bednarz, 1975: 23):

1. Factors that influence assessors to adjust values that are not related to market value;

2. Factors that affect the market, but are not acknowledged properly by assessors; and

3. Factors that are valued differently by assessors and the market.

Potential influences, represented by independent variables in an econometric model, should not have high levels of explanatory power because those influences should equally affect the numerator and denominator (Berry and Bednarz 1975; Goolsby 1997). That is, those influences should affect the 
assessed value and sale price equally. The more variance explained by potential influences of these characteristics under each system, the more the system leads to inherent systematic bias.

This study focuses on two systems using data points (i.e., parcels) as the units of analysis. Analyzing systematic bias in a county that changed its assessment practices from a non-market value standard (reproduction cost) to a standard that is driven by market values in search of fairness is a unique opportunity. This study is not focused on assessors' qualities and their ability to reduce the disparity between comparable properties, but on how tax burden is or is not affected by systems with or without inherent biases built into the valuation standard.

\section{Data and Descriptive Analyses}

Marion County (primarily Indianapolis), Indiana, serves as an ideal case for this analysis. Marion County contains an adequate amount of social diversity and diversity in housing stock. Also, it was part of a 2002 state-level assessment reform that required mass assessment adjustment of all properties in the county under a different assessment system. The change occurred for all properties at the same time, which allows the impact of assessment changes on property tax burden to be tested under what effectively may be considered a quasi-experimental design.

The primary data sources for this analysis come from a Multiple Listing Service (MLS) provided by the Metropolitan Indianapolis Board of REALTORS ${ }^{\circledR}$ (MIBOR) and parcel level data provided by the Marion County Assessor's Office. All single-family residential listings recorded in the MIBOR MLS from 1999 to present are accessible. That proprietary database includes approximately 200 potential variables, including fairly complete sales prices, unit characteristics (e.g., age, square footage, property acreage), and location attributes (e.g., location coordinates, township, parcel identification). MIBOR estimates that approximately 80 percent of all properties sold in their service area during the study period are listed in the MLS database.

Parcel level assessment data from the township assessors includes all residential parcels for assessment years 2000, 2001, 2004, and 2005, with fields for parcel identification, property type 
identification, and gross assessed value. ${ }^{4}$ The data straddle the 2002 assessment reform that occurred in Indiana and led to a switch in assessment practices from a non-market value assessment standard to a market value assessment standard. The two primary data sources are merged by a parcel identification number. Other necessary neighborhood characteristics are obtained from publicly accessible secondary sources (e.g., Bureau of the Census) and spatially joined through the use of a geographic information system.

The data are separated into two subsamples, NON-MARKET and MARKET. The NONMARKET sample allows for analysis of assessment equity prior to assessment reform in Marion County, Indiana. The MARKET sample allows for analysis of assessment equity in the same county after assessment reform. Each property’s most recent, prior assessment was used in the analysis.

The data are cleansed of obvious data entry errors, non-arm's length transactions, vacant parcels, and properties on which improvements had not been assessed (property assessment typically lags new construction by approximately two years $)^{5}$. The resulting dataset includes 35,432 observations across all years studied. Table 1 shows the number of observations for each year studied by township. Townships were the primary unit of government responsible for property tax assessment during the study period. The number of observations each year ranges from 8,148 to 9,344 for the entire county.

Table 2 summarizes the typical measures used to analyze level of assessment, horizontal equity, and vertical equity. The level of assessment is measured by the jurisdictional median assessment-sales ratio. Horizontal equity is measured by the coefficient of dispersion (COD), and vertical equity is measured by the price-related differential (PRD).

The county-wide median ratios for the NON-MARKET sample were 0.52 each year. The annual county medians of the MARKET sample were 0.88 and 0.85 . Median assessment-sales ratios across townships during years before assessment reform range from 0.38 (Washington Township, AY2001) to 0.60 (Pike Township, AY2000), a 74 percent difference.

After assessment reform to the market value standard, the township values range from 0.76 (Washington Township, AY2005) to 0.97 (Decatur Township, AY2004), a 28 percent difference. Annual 
comparisons are fairly consistent for each township before and after assessment reform. Only two townships (Decatur and Franklin) meet the 0.90 to 1.10 IAAO standard of acceptability in both assessment years after assessment reform. Two additional townships (Pike and Warren) meet the standard in the first year reported after assessment reform. As expected in an assessment system with no reference to market value, none of the township assessed values prior to assessment reform are near that standard. That finding illustrates the lack of transparency in formula-based, non-market driven assessments. Generally, the variation in level of assessment (median jurisdictional A/S) shows inter-jurisdictional differences that ultimately may lead to unfair tax distribution when taxing districts overlap multiple townships.

The overall COD for Marion County does not meet the IAAO’s standard, which states that the COD should be within 10 to 15 percent of the median A/S value. The slightly lower COD values show that the market value system is only marginally more uniform than the non-market value system. The most common measure for vertical equity, PRD, shows inconsistency in levels of vertical inequity. Lower priced homes were generally over-assessed relative to higher priced homes in both samples (PRD>1.0), with the exception of one township (Perry Township). This result indicates regressivity in both systems. County PRD measures are above the IAAO standard (0.98-1.03) in both samples, though the MARKET sample PRD indicates that higher priced properties were under-assessed to a greater extent following assessment reform. The following sections explain the methodological approach and results of seeking whether or not the disparities found through the previous descriptive analyses is likely due to systematic error inherent in the standards.

\section{Estimating Systematic Bias Under Two Disparate Assessment Standards}

The test for systematic bias in both valuation methods is operationalized by regressing potential influences on the assessment-sales ratios in both samples, NON-MARKET and MARKET. The selection of potential influences is guided by the few studies addressing systematic bias and the assessment uniformity literature, though several adaptations were necessary to fit the purposes of this study and the units of analysis used. Theoretical and empirical inferences from previous literature suggest that housing 
characteristics and neighborhood characteristics may influence assessment errors. Other influences may be related to assessor characteristics and time of sale. Equation 1 illustrates those relationships.

$$
\mathrm{A} / \mathrm{S}=\beta_{0}+\beta_{\mathrm{k}} \mathrm{S}_{\mathrm{k}}+\beta_{\mathrm{j}} \mathrm{L}_{\mathrm{j}}+\beta_{\mathrm{h}} \mathrm{R}_{\mathrm{h}}+\beta_{\mathrm{g}} \mathrm{T}_{\mathrm{g}}+\mathrm{e}
$$

Where:

$\mathrm{A} / \mathrm{S}=$ a vector of assessment-sales ratios

$\mathrm{S}_{\mathrm{k}}=$ vector of property characteristics

$\mathrm{L}_{\mathrm{j}}=$ vector of locational characteristics

$\mathrm{R}_{\mathrm{h}}=$ vector of jurisdiction variables

$\mathrm{T}_{\mathrm{g}}=$ Time

$\beta_{0}, \beta_{\mathrm{k}}, \beta_{\mathrm{j}}, \beta_{\mathrm{h}}$, and $\beta_{\mathrm{g}}=$ corresponding parameters

$\mathrm{e}=$ vector of errors

Like previous studies on assessment uniformity, a semi-log model is used (Bowman and Mikesell 1978, Bowman and Butcher 1986). The natural log transformation of the dependent variable is justified to reduce heteroskedasticity that is associated with highly-skewed values. ${ }^{6}$ That transformation also is theoretically appropriate given that the marginal effects of the determinants are likely relative to the observed level of assessment for each observation.

Table 3 summarizes the determinants expected to systematically affect assessment accuracy. As mentioned previously, the log transformed assessment level is the dependent variable. Property characteristics include the square feet of unimproved land, proportion of the parcel that is unimproved, age of the property, and square feet. Unimproved land is assessed separately in both assessment systems as if the land had no improvements. It is difficult to foretell the expected sign of the two unimproved land variables. One of those variables (Sqft Unimproved Area) addresses the potential effect of the absolute size of land on the parcel. The other (Proportion Parcel Unimproved) addresses the amount of land relative to the footprint of the house. It is reasonable to assume that valuation of land without improvements is difficult and may lead to bias in the assessment-sales ratio. If land value is underassessed, then capital improvements will be overly taxed. Bias associated with land could lead to distortions in the land-capital mix (Berry and Bednarz 1975)

Property age likely is an important determinant. Mikesell (2004) found that the non-market assessment process, relying heavily upon depreciation tables with no reference to market conditions, 
generally led to bias. With more weight on depreciation than the market, Mikesell (2004) found that older homes were more likely to be under-assessed. In a market-value driven assessment system, the age factor may be expected to be less correlated with assessment-sales ratios. Other scholars who have tested the effect of housing unit age on systematic assessment bias using the assessment-sales ratio as a dependent variable found that even assessors operating under market-driven standards tend to under value older properties. That is, assessors tend to depreciate the improved value of a property more rapidly than homebuyers (Berry and Bednarz 1975; Goolsby 1997).

The total square feet of a residential house also may affect the assessment-sales ratio systematically. Whether assessed values are based on reproduction costs (NON-MARKET) or replacement costs (MARKET VALUE), it is possible that those values and market values for square footage are not equal (Berry and Bednarz 1975; Goolsby 1997). It is difficult to determine a priori whether or not one should expect a different, or larger, effect under one valuation standard versus the other.

Neighborhood characteristics in the model include the proportion of non-white residents, median neighborhood household income, proportion of housing structures rented, proportion of non-seasonal vacant properties that are not listed for rent or sale, and the proportions of older and newer units in the census tract in which each observation is located. Several previous studies have tested the effect of race and income on assessment quality (Black 1972; Berry and Bednarz 1975; Schroeder \&Sjoquist 1976; Almy 1977; Ihlanfeldt and Jackson 1982; Haurin 1988; Goolsby 1997; Strauss and Strauss 2004). Empirically, those studies have found that race and income matter.

Researchers generally have concluded that the dominance of non-white residents is related to over-assessment or lack of uniformity in assessment. One line of reasoning is that assessors make prejudicial judgments against geographic concentrations of minority residents. Over-assessment in neighborhoods with higher proportion of non-white residents also may be a product of the valuation standard, types of housing occupied by the non-white residents, and the nature of the housing market (Strauss and Strauss 2004). 
Correlation between assessment error and the presence of vacant properties also has been empirically found. Jurisdictions with greater concentrations of vacant properties have been found to be less uniform (Bowman and Butcher 1986; Bowman and Mikesell 1978; Bowman and Mikesell 1990). Systematically biased assessments might be expected as the proportion of nearby single-family vacancies increase. One may expect vacant properties to have a greater negative effect on market values than on assessed values because assessors may not adequately value negative externalities. A non-market based assessment may more likely be related to bias since the effect of those externalities has no relevance.

Some scholars have suggested lack of assessment uniformity may be associated with lower income neighborhoods because lower income residents are less likely to have political clout (Bowman and Mikesell 1978; Bowman and Mikesell 1990). In Indiana, the assessor is an elected position. Researchers have empirically found that elected assessors' jurisdictions are less uniform than appointed assessors’ jurisdictions (Bowman and Mikesell 1978; Bowman and Mikesell 1990; Ross 2011). The rational conclusion is that the lack of uniformity is biased toward over-assessment. If neighborhoods with concentrations of lower income residents are over-assessed relative to higher income residents, then one may conclude that the administration of the tax has led to a regressive tax base. As with over-assessment associated with the proportion of non-white population, over-assessment in lower income neighborhoods also may be a product of the valuation standard, types of housing occupied by lower income residents, and the nature of the housing market.

Market heterogeneity also is expected to affect assessment levels, ceteris paribus. Several studies have tested different measures of market heterogeneity, including age and sales price heterogeneity (Schroeder and Sjoquist 1976; Bowman and Butcher 1986; Chicoine and Geirtz 1988). Relative neighborhood heterogeneity is tested in this study by categorizing various properties into aggregated age cohorts reported in the 2000 Decennial Census (US Census Bureau 2004). Specifically, the proportion of structures in a census tract is calculated for the following age cohorts: before 1940; 1940 to 1969; 1970 to1990; and 1990 to 1999. 
The proportion of units outside of each observation's cohort was calculated. The variable, Proportion Older, is the proportion of properties within each observation's Census Tract that were built in prior age cohorts. Proportion Newer is the proportion of units built after each observation's cohort. Together, those variables provide a measure of relative property heterogeneity in the neighborhood of each observation. In effect, Proportion Older and Proportion Newer measure the relative age of each observation to other properties in the neighborhood. If a higher proportion of properties are within the same cohort as the observation, one may expect less systematic bias. Tested separately, potential variations between older and newer concentrations of properties and the observations may be examined. The direction and magnitude may differ between by proportions of properties built in older or newer cohorts.

Frequency of surrounding sales may be an important influence of systematic bias in different ways (McMillenand Weber 2008). Properties in thicker rather than thinner markets may be valued with less error if assessed values are influenced by market value. However, greater frequency of sales surrounding a property may be an indication of demand in the surrounding neighborhood and may be expected to have a positive relationship with house price that is not reflected in an assessor's valuation. The frequency of sales is calculated by counting the number of sales that occurred within a one-mile radius around the property in both samples. The use of a one-mile radius was chosen from preliminary analyses on the effect of frequency on property sales price.

Township and year variables account for potential unobservable effects. The township location of the each parcel was identified in the assessment records. Townships envelop location effects. As the jurisdiction with primary responsibility of assessment, townships include unobservable effects of assessment administration. They also account for differential market effects on price that may not be reflected in assessed values. ${ }^{7}$ Townships' estimates will indicate whether or not there is a differential effect among township assessments holding other property and neighborhood characteristics constant. 
The binary Year variable adjusts the intercept for time. The base year is the first year in each sample. The base year is the omitted variable for each model and the subsequent year is reported as a differential coefficient from that base year.

Table 4 shows the mean and standard deviation for each of the variables used to examine systematic bias in each sample. The MARKET and NON-MARKET samples contain 17,036 and 18,396 observations, respectively. As with any study using sales prices as a proxy for market values, there is potential for sample selection bias (Gatzlaff and Haurin 1998). That is, the properties sold during the study period may not be representative of all single-family residential properties in the study area (Allen and Dare 2002). Data limitations prevent identifying the direction of the potential bias associated with sample selection. However, examination of the means and standard deviations of the two time periods considered in this study show that the samples are generally comparable across property and neighborhood characteristics. The distributions across townships and years sold also are similar. The greatest differences are between A/S, and the Nominal Tax Rate variable.

The MARKET sample A/S mean is 73 percent higher than the NON-MARKET sample mean. This is the result of a shift in all assessments. The shift does not translate into an average 73 percent increase in effective tax rate. All properties’ A/S shifted as a result of assessment reform. The variation around the mean A/S for each sample is comparable. One standard deviation is (+/-) 34 percent and (+/-) 31 percent of the mean for the NON-MARKET and MARKET samples, respectively. The dependent variable, A/S, is transformed to its natural log. Therefore, the results can be interpreted proportionally. That is, the effect of one unit change in each independent variable on A/S is interpreted as the marginal percentage change.

The shift in nominal tax rate reflects the shift from what was essentially a fractional assessment standard to one in which the goal is full market value. The mean nominal tax rate of the MARKET sample is just over one-third the same rate in the NON-MARKET sample. Like the variation around the mean $\mathrm{A} / \mathrm{S}$, the variation around the mean nominal tax rate for each sample is comparable. One standard 
deviation is (+/-) 11 percent and (+/-) 9 percent of the mean for the NON-MARKET and MARKET samples, respectively.

\section{Results}

Table 5 shows the OLS results of the NON-MARKET and MARKET models. The models explain 35 percent of the variance in the NON-MARKET sample and 12.5 percent of the variance in MARKET sample. These findings raise issues that continually will be difficult to address. First, the uniformity of assessment-sales ratios is only slightly better after assessment reform (See table 2). The coefficients of dispersion in Table 2 indicate that the average distribution of assessment-sales ratios from the global median (county median) is between 21 percent and 28 percent for each of the assessment years studied — a difference of seven percentage points — and both well above the IAAO acceptable equity standard. On the other hand, systematic variation explained by the $\ln (\mathrm{A} / \mathrm{S})$ models for the samples is quite different. The variance explained by the model of non-market value assessments $\left(\mathrm{R}^{2}=0.35\right)$ is nearly three times greater than the variance explained by the model of market value assessments $\left(\mathrm{R}^{2}=0.13\right)$. Therefore, the market value system may have less built-in bias, but is only slightly more uniform as a whole; based more heavily upon unexplained variation. ${ }^{8}$ Secondly, some systematic bias still remains in the newer, presumably fairer, market-based assessment process. Further examination of the models indicates that many of the variables that are significant in the NON-MARKET sample are also significant in the MARKET sample.

The coefficients may be multiplied by 100 to represent marginal percentage change in A/S for a one unit increase in each independent variable. Two of the five property determinants were significantly related to assessment-sales ratio before assessment reform at $p<0.05$. Significant unimproved land size effects exist in both samples. The land effect in the NON-MARKET sample is proportional, relative to the footprint of the housing structure on the parcel. The land effect in the MARKET sample is on the absolute size of the unimproved portion of the parcel. After assessment reform to the market value standard, five of the same seven neighborhood determinants had a significant effect on $\ln (\mathrm{A} / \mathrm{S})$ at $p<0.05$. The 
proportion non-white population, proportion vacant, proportion built before, frequency of sales, and nominal tax rate all have the same directional effects (though there is a difference in magnitude between the two samples) on $\ln (\mathrm{A} / \mathrm{S})$. One variable, proportion of neighborhood properties in the cohort built after each observation, was not significant at $p<0.05$ in the NON-MARKET sample and significant at $p<0.05$ in the MARKET sample. The results show significant location (i.e., townships) and sales year ( $\left.\mathrm{Year}_{\mathrm{t}+1}\right)$ effects in both samples.

Generally, tax burdens decrease significantly before and after assessment reform as structure age, square feet of living area, frequency of sales in the neighborhood, and nominal tax rate increase. The negative relationship between structure age and $\ln (\mathrm{A} / \mathrm{S})$ is linear after switching to market value assessment, but it is exponentially related before assessment reform. Tax burdens increase significantly before and after assessment reform as the proportion non-white population and proportion vacant structures increases. The binary township variables show some variation between the assessment jurisdictions. All townships' coefficients are referenced to Center Township, since it is the omitted variable.

\section{Summary and Discussion}

The estimates presented in table 5 can be compared graphically to illustrate the magnitude of bias associated with various property and neighborhood attributes. Four property characteristics and two neighborhood characteristics are chosen for further investigation, including: Structure Age, Sqft Unimproved Area, Proportion Parcel Unimproved, Sq ft Living Area, Proportion Non-white, and Proportion Vacant. Each graphic illustrates the magnitude of the coefficients.

The graphs should be viewed cautiously. They are for illustrative purposes only because the average house does not exist. ${ }^{9}$ The graphs compare the magnitude of each factor between two separate samples and models. They reflect the disparity that exists by manipulating each attribute, while holding all other attributes constant. The illustrations represent the approximate middle 80 percent (the bottom and top 10 percent of properties for each variable were trimmed for each graphic) of the data for each 
variable. Solid lines indicate that the estimated effect is significant and the dashed lines indicate that the effect is statistically insignificant at $p<0.05$.

The marginal effect of attribute change displayed in the following figures is based on the percentage difference from the median county level of assessment. This adjustment allows for a comparison of the two samples on similar scales. Table 6 shows the median and average assessment-sales ratios for each sample. That table also shows the percentage difference of the average property A/S ratio from the median A/S.As indicated, the NON-MARKET sample mean A/S is 53.11, which is 1.7 percent higher than the sample median 52.20. The MARKET sample mean (92.37) is 6.8 percent higher than the sample median 86.44 .

\subsection{Property Specific Bias}

Figure 1 through figure 4 illustrate the relationship of the property specific variables separately, holding all other factors constant. Figure 1 compares the magnitude of property age bias under both assessment processes. The Structure Age variable has been transformed to the year the structures were built. That figure shows a much greater disparity associated with property age prior to Indiana's transition to market value assessment.

Specifically, Figure 1 shows the average house (varying only in age) built after 2000 has an estimated $\mathrm{A} / \mathrm{S}$ ratio that is over 40 percent higher than the sample median before assessment reform to the market value standard. That same house built prior to 1940 has an expected A/S ratio that is more than 15 percent below the same sample (NONMARKET) median. There was substantially more burden for newer properties under the non-market value assessment standard. These results are similar to Mikesell's (2004) findings across many counties in his study of non-market value assessment in Indiana. The estimated age disparity after switching to the market value assessment standard ranges from greater than 10 percent below to less than 10 percent above the median for homes built between 1920 and 2005.Comparisons of the two samples illustrate the substantial tax burden shifts between property owners of newer homes to 
property owners with older homes as result of reform from non-market value assessment to market value assessment.

The bias associated with square feet of living area before and after assessment reform is shown in figure 2.Specifically, that figure shows both standards place greater tax burden on smaller homes than larger homes. That is, homebuyers seem to place slightly more value than assessors on the size of the house. However, the magnitude of the bias associated with house size is negligible in both samples.

Figure 3 and figure 4 illustrate the comparison A/S bias as a result of the amount of unimproved land on a parcel before and after assessment reform. The market value standard, as administered during the study period, tended to place a subsidy on land, introducing greater tax burden on improvements (holding all other factors constant, including house size).The subsidy placed on land after assessment reform (as illustrated by figure 4) may distort the land-capital mix (Berry and Bednarz, 1975).Overassessment of land may reduce the intensiveness of land use and reduce capital investment. The proportion of unimproved land before assessment reform was positive and significant, but the magnitude of that effect is trivial.

\subsection{Neighborhood Bias}

Figure5 and figure 6 show the direct effect of selected neighborhood variables separately, holding all other factors constant. Figure 5 compares the magnitude of bias associated with the proportion nonwhite population under both assessment standards. The administration of both systems led to the overassessment of residential properties in neighborhoods with higher proportions of non-white residents. The disparity of tax burden between higher and lower neighborhood concentrations of non-white residents due to assessment bias is smaller under the market value standard. This illustrates an unintended consequence of an assessment standard that is not related to market value (NON-MARKET sample).

As shown in figure 6, the proportion of vacancies in a neighborhood creates greater disparities in the non-market based assessment. This finding may be expected. The market-driven assessment should better account for the externalities associated with distressed neighborhoods. This is an important finding 
as one considers the effect of private decisions and public consequences. The decision of private home owners to abandon a property likely affects the property value of surrounding residents. A tax system that does not consider this type of externality increases the negative effect of such decisions by over taxing homeowners in neighborhoods with more distressed properties.

\subsection{General Policy Implications}

The property tax will likely continue to be a major local government revenue source in the United States despite the public perception that it is inherently unfair and political pressure to eliminate its use (Jensen 1931; Aaron 1975; Case 1978; Almy 1982).However, historical patterns indicate that political pressure may continue to place limits on its use or alter how it is administered. The findings presented here have implications for property tax policy in the context of such pressures.

State laws and standards that result in property tax assessments that diverge from market value can directly affect fairness and equity of tax burden. The findings of this and other studies (Bowman and Butcher 1986; Bowman and Mikesell 1990; O’Sullivan et al. 1994; Sexton et al. 1999) show that standards other than full market value can lead to unintended consequences. Indiana's non-market value assessment system, while unique, provides a base from which to judge market-value assessment standards. The determination of assessed values under the non-market value system in Marion County, Indiana was driven by the age of properties. The unintended consequence was that owners of newer properties paid higher effective tax rates than owners of older properties, ceteris paribus. No single dominant determinant systematically affected the level of assessment under the market value standard like age of property under the non-market value standard.

State regulatory bodies and legislators should recognize that the market value standard alone does not guarantee equitable property tax burden. Quality administration of the standard is critical, especially in terms of the efficiency of the property tax. The findings in this study show that the market value assessment standard in the area studied led to global inequity that was nearly equal to the systematic inequity experienced under the non-market assessment system. This underscores the fact that while 
systematic bias in an assessment system is inherently inequitable, unexplained assessment error that is associated with poor assessment performance may still exist. The focus should be on addressing that unexplained assessment error.

\footnotetext{
${ }^{1}$ Two previous studies have examined the equity impact of Indiana's non-market valuation standard. Smith (2000) examined typical vertical equity measures in Bloomington, Indiana. Evidence from Smith's analysis suggests that the non-market valuation standard employed in that city resulted in a progressive property tax structure. Smith cautioned that his findings may be limited and further examination of the relationship between assessment equity and property characteristics (e.g., location, age of structure, and demographic characteristics) may be beneficial for understanding valuation standards that do not attempt to objectively reflect property wealth. Mikesell's (2004) interjursidictional (i.e., aggregate county equity measures) study of Indiana's non-market valuation standard found considerable equity discrepancies across counties. Examination of Indiana county level measures used by Mikesell does not show a consistent pattern suggesting that the inequity associated with the non-market valuation standard was an artifact of urban versus rural property location.

${ }^{2}$ Less systematic bias is referring to the difficulty of identifying dominant determinants of assessment bias.

${ }^{3}$ Improvements are constructed features added to the land (e.g., buildings, sheds, pools).

${ }^{4}$ Electronically formatted data were not available to the author for 2002 or 2003.

${ }^{5}$ Indiana assessments are separated by improvement assessed value and land assessed value. New construction (i.e., new improvements) is not assessed immediately after construction. Typically, new construction is assigned a relatively low improvement assessed value (e.g., \$200). This indicates that there have been new improvements, but the improvements have not been assessed. Examination of the data shows an approximate two year period between new construction and assessment of improvements. ${ }^{6}$ Initial models were estimated without the log transformation. The results empirically indicated a significant problem with heteroskedasticity.

${ }^{7}$ Preliminary models included tax intensity variables by township, which were consistently insignificant. Once it was clear those observed measures (e.g., proportion of residential assessed value) had no effect, binary location variables were tested to see if unobserved effects within townships had an effect (Bowman and Mikesell 1990; Bowman \& Butcher 1986).

${ }^{8}$ At the suggestion of an anonymous reviewer, additional models excluding time invariant neighborhood characteristics extracted from the 2000 Biennial Census were tested. The purpose of those models is to examine the robustness of conclusions drawn from the differences in explained variation. The variation explained by the models dropped from 34.9 percent to 25.1 percent for the non-market valuation model and from 12.5 percent to 9.5 percent for the market valuation model. Even after the exclusion of Census extracted variables, the variation explained was over two times greater for the non-market value model than for the market value model.

${ }^{9}$ For instance, no property can be located proportionally across all townships.
} 


\section{References}

Aaron, Henry J. 1975. Who Pays the Property Tax? A New View Washington D.C: Brookings Institution.

Allen, Marcus T., and William H. Dare. 2002. Identifying Determinants of Horizontal Property Tax Inequity: Evidence from Florida. Journal of Real Estate Research, 24(2), 153-164.

Almy, Richard. 1982. Historical Patterns and Trends in the Jurisdictional Setting of Property Tax Administration. Property Tax Journal, 1(March), 75-83

Almy, Richard. 1977. The Impact of Assessment Practices Upon Assessment Performance. In Almy, Richard ed. Analyzing Assessment Equity. Chicago, IL: 153-204.

Bennett, David J., and Stephanie E. Stullich. 1992. Financing Local Government in Indiana. Fort Wayne, IN: Lincoln Printing Corporation.

Berry, Brian J., and Robert S. Bednarz. 1975. A Hedonic Model of Prices and Assessments for SingleFamily Homes: Does the Assessor Follow the Market or the Market Follow the Assessor? Land Economics, 51(1), 21-40.

Black, David E. 1972. The Nature and Extent of Effective Property Tax Rate Variation Within the City of Boston. National Tax Journal, 25, 203-210.

Bowman, John H., and William A. Butcher. 1986. Institutional Remedies and the Uniform Assessment of Property: An Updated Extension, National Tax Journal, 39(June), 157-169

Bowman, John H., and John L. Mikesell. 1990. Assessment Uniformity: the Standard and Its Attainment, Property Tax Journal, 9, 219-34.

Bowman, John H., and John L. Mikesell. 1978. Uniform Assessment of Property: Returns from Institutional Remedies, National Tax Journal, 31, 137-53.

Case, Karl E. 1978. Property Taxation: The Need for Reform, Cambridge, MA: Ballinger Publishing Company.

Chamberlain, Andrew. 2007. What Does America Think About Taxes? The 2007 Annual Survey of U.S. Attitudes on Taxes and Wealth. Tax Foundation Special Report No. 154.

Chicone, David L., and Fred J. Giertz. 1988. Uniformity in a Dual Assessment System, National Tax Journal, 4, 247-256.

Cole, Richard L., and John Kincaid. 2006. Public Opinion on U.S. Federal and Intergovernmental Issues in 2006: Continuity and Change, Publius: The Journal of Federalism, 36(3), 443-459.

Cornia, G.C., and Slade, B.A. 2005. Assessed Valuation and Property Taxation of Multifamily Housing: An Empirical Analysis of Vertical and Horizontal Equity and Assessment Methods. The Journal of Real Estate Research, 21(1), 17-46.

Department of Local Government Finance. 2000. 2002 Real Property Tax Assessment Manual. Indianapolis, IN: State of Indiana. 
Fisher, Glenn W. 1996. The Worst Tax? A History of the Property Tax in America. Lawrence, KS: University Press of Kansas.

Gatzlaff, Dean H., and Haurin, Donald R. 2001. Sample Selection and Biases in Local House Value Indices. Journal of Urban Economics, 43(2), 199-222.

Geraci, Vincent J. 1977. Measuring the Benefits from Property Tax Assessment Reform, National Tax Journal, 30, 195-205

Geraci, Vincent J., and James L. Plourde. 1976. The Determinants of Uniform Property Tax Assessment. Assessors Journal, 11, 231-251.

Goolsby, William C. 1997. Assessment Error in the Valuation of Owner-Occupied Housing. Journal of Real Estate Research, 13(1), 33-44

Haurin, Donald R. 1988. An Empirical Analysis of Property Tax Equity. Property Tax Journal. 5-18

Ihlandfeldt, Kieth R. and John D. Jackson. 1982. Systematic Assessment Error and Intrajurisdictional Property Tax Capitalization. Southern Economic Journal, 49(2), 417-27

International Association of Assessing Officers. 2009. State and Provincial Ratio Study Practices: Results of 2008 Survey. Journal of Property Tax Assessment and Administration. 6(2), 29-81.

International Association of Assessing Officers [IAAO]. 1999. Standard on Ratio Studies. Assessment Journal. 6(5), 23-64

Jensen, Jens P. 1931. Property Taxation in the United States. Chicago, IL: University of Chicago Press.

Lowery, David. 1982. Public Choice When Services are Costs: The Divergent Case of Assessment Administration. American Journal of Political Science, 26(1), 57-76

McMillen, Daniel P., and Rachel N. Weber. 2008. Thin Markets and Property Tax Inequities: A Multinomial Logit Approach. National Tax Journal, 61(4), 653-671.

Mikesell, John L. 2004. Equity Impacts of a Non-Market Property Assessment Standard: Evidence from the Indiana Administrative Formula Approach. Journal of Property Tax Assessment and Administration, 5(3), 37-72.

Musgrave, Richard A., and Peggy B. Musgrave. 1989. Public Finance in Theory and Practice (Fifth Edition), New York, NY: McGraw Hill

Oates, Wallace E. 1999. Local Property Taxation: An Assessment. Assessment Journal. 6(5): 67-69.

Oates, Wallace E. 2000. Property Taxation and Local Government Finance: An Overview and Some Reflections. In Property Taxation and Local Government Finance, W.E. Oates, (Ed.) Toronto, Ontario Canada, Lincoln Institute of Land Policy.

O’Sullivan, Arthur, Terri A. Sexton, Terri A., and Steven M. Sheffrin. 1994. Differential Burdens from the Assessment of Proposition 13. National Tax Journal. 48 (December), 721-730. 
Ross, Justin M. 2011. Assessor Incentives and Property Assessment. Southern Economic Journal. 77(3), 776-794.

Seligman, Edwin R.A. 1985. Essays in Taxation. New York, N.Y.: MacMillan

Sexton, Terri A., Steven M. Sheffrin, and Arthur O’Sullivan. 1999. Proposition 13: Unintended effects and Feasible Reforms. National Tax Journal,. 52 (March), 99-112.

Schroeder, Larry, and David L. Sjoquist. 1976. An Investigation of the Causes of Variations in Property Tax Assessment. Assessors Journal, 11, 221-234.

Shannon, John. 1969. Conflict Between State Assessment Law and Local Assessment Practice. Property Taxation-USA.Edited by R.W. Lindholm. Madison: University of Wisconsin.

Sjoquist, David L., and Lakshmi Pandey. 2001. An Analysis of Acquisition Value Property Tax Assessment for Homestead Property. Public Budgeting \& Finance, (Winter), 1-17

Slemrod, Joel. 1995. Professional Opinions about Tax Policy: 1994 and 1934. National Tax Journal, 48(1), 121-147.

Smith, Adam. 1776. The Wealth of Nations. Book IV, Chapter II, Part II

Strauss, Robert P., and David A. Strauss.(2004). Residential Real Estate Assessment Fairness in Four Urban Areas. State Tax Notes 31, 10, p815-820

U.S. Advisory Commission on Intergovernmental Relations (USACIR) (1989).Changing Public Attitudes on Governments and Taxes. Washington D.C.: U.S Government Printing Office.

U.S. Bureau of the Census (2004).Census 2000 Summary File 3 


\section{Author Biography}

Seth B. Payton is an assistant professor of public affairs in the Indiana University School of Public and Environmental Affairs on the Indiana University-Purdue University Indianapolis campus. He earned his Ph.D. in public affairs at Indiana University with concentrations in public finance and policy analysis and a minor in geography. He also is a faculty fellow at the Indiana University Public Policy Institute. 
Tables

Table 1: Sample Size by Year and Township

\begin{tabular}{|c|c|c|c|c|}
\hline \multirow[b]{3}{*}{ TOWNSHIPS } & \multicolumn{4}{|c|}{$\begin{array}{c}\text { SAMPLE SIZE } \\
\text { (Proportion of Sample) }\end{array}$} \\
\hline & \multicolumn{2}{|c|}{ NON-MARKET } & \multicolumn{2}{|c|}{ MARKET } \\
\hline & AY 2000 & AY 2001 & AY2004 & AY2005 \\
\hline Center & $\begin{array}{r}1,246 \\
(15.3 \%)\end{array}$ & $\begin{array}{r}1,300 \\
(14.6 \%)\end{array}$ & $\begin{array}{r}1,191 \\
(12.7 \%)\end{array}$ & $\begin{array}{r}1,208 \\
(13.3 \%)\end{array}$ \\
\hline Decatur & $\begin{array}{r}206 \\
(2.5 \%) \\
\end{array}$ & $\begin{array}{r}231 \\
(2.6 \%) \\
\end{array}$ & $\begin{array}{r}277 \\
(3.0 \%)\end{array}$ & $\begin{array}{r}228 \\
(2.5 \%)\end{array}$ \\
\hline Franklin & $\begin{array}{r}380 \\
(4.7 \%)\end{array}$ & $\begin{array}{r}393 \\
(4.4 \%) \\
\end{array}$ & $\begin{array}{r}583 \\
(6.2 \%)\end{array}$ & $\begin{array}{r}507 \\
(5.6 \%)\end{array}$ \\
\hline Lawrence & $\begin{array}{r}1,207 \\
(14.8 \%)\end{array}$ & $\begin{array}{r}1,356 \\
(15.3 \%)\end{array}$ & $\begin{array}{r}1,328 \\
(14.2 \%)\end{array}$ & $\begin{array}{r}1,322 \\
(14.6 \%)\end{array}$ \\
\hline Perry & $\begin{array}{r}798 \\
(9.8 \%) \\
\end{array}$ & $\begin{array}{r}874 \\
(9.8 \%) \\
\end{array}$ & $\begin{array}{r}1,027 \\
(11.0 \%) \\
\end{array}$ & $\begin{array}{r}981 \\
(10.8 \%) \\
\end{array}$ \\
\hline Pike & $\begin{array}{r}843 \\
(10.3 \%) \\
\end{array}$ & $\begin{array}{r}969 \\
(10.9 \%) \\
\end{array}$ & $\begin{array}{r}1,004 \\
(10.7 \%) \\
\end{array}$ & $\begin{array}{r}982 \\
(10.8 \%) \\
\end{array}$ \\
\hline Warren & $\begin{array}{r}1,050 \\
(12.9 \%)\end{array}$ & $\begin{array}{r}1,080 \\
(12.2 \%)\end{array}$ & $\begin{array}{r}1,170 \\
(12.5 \%)\end{array}$ & $\begin{array}{r}1,049 \\
(11.6 \%)\end{array}$ \\
\hline Washington & $\begin{array}{r}1,260 \\
(15.5 \%)\end{array}$ & $\begin{array}{r}1,358 \\
(15.3 \%)\end{array}$ & $\begin{array}{r}1,424 \\
(15.2 \%)\end{array}$ & $\begin{array}{r}1,517 \\
(16.8 \%)\end{array}$ \\
\hline Wayne & $\begin{array}{r}1,158 \\
(14.2 \%)\end{array}$ & $\begin{array}{r}1,327 \\
(14.9 \%)\end{array}$ & $\begin{array}{r}1,340 \\
(14.3 \%)\end{array}$ & $\begin{array}{r}1,258 \\
(13.9 \%)\end{array}$ \\
\hline Marion County & $\begin{array}{r}8,148 \\
(100 \%)\end{array}$ & $\begin{array}{r}8,888 \\
(100 \%)\end{array}$ & $\begin{array}{r}9,344 \\
(100 \%)\end{array}$ & $\begin{array}{r}9,052 \\
(100 \%)\end{array}$ \\
\hline
\end{tabular}


Table 2: Level of Assessment, Horizontal Equity, and Vertical Equity

\begin{tabular}{l|r|r|r|r}
\hline \multirow{2}{*}{ TOWNSHIPS } & \multicolumn{2}{|c}{ Level of Assessment (Median Assessment Ratio) } \\
\cline { 2 - 5 } Center & AY 2000 & AY 2001 & \multicolumn{1}{c}{ AY2004 } & \multicolumn{1}{c}{ AY2005 } \\
\hline Decatur & 0.43 & 0.41 & 0.83 & 0.78 \\
\hline Franklin & 0.56 & 0.58 & 0.97 & 0.92 \\
\hline Lawrence & 0.55 & 0.55 & 0.93 & 0.92 \\
\hline Perry & 0.57 & 0.56 & 0.86 & 0.84 \\
\hline Pike & 0.49 & 0.51 & 0.89 & 0.86 \\
\hline Warren & 0.60 & 0.59 & 0.91 & 0.88 \\
\hline Washington & 0.51 & 0.50 & 0.92 & 0.87 \\
\hline Wayne & 0.42 & 0.38 & 0.77 & 0.76 \\
\hline Marion County & 0.51 & 0.52 & 0.91 & 0.86 \\
\hline
\end{tabular}

Horizontal Equity (Coefficient of Dispersion)

\begin{tabular}{l|r|r|r|r}
\hline \multirow{2}{*}{ TOWNSHIPS } & \multicolumn{2}{|c|}{ NON-MARKET } & \multicolumn{2}{c}{ MARKET } \\
\cline { 2 - 5 } Center & AY 2000 & AY 2001 & AY2004 & \multicolumn{1}{c}{ AY2005 } \\
\hline Decatur & 0.58 & 0.67 & 0.63 & 0.58 \\
\hline Franklin & 0.18 & 0.18 & 0.15 & 0.14 \\
\hline Lawrence & 0.11 & 0.13 & 0.12 & 0.11 \\
\hline Perry & 0.15 & 0.15 & 0.15 & 0.13 \\
\hline Pike & 0.18 & 0.18 & 0.14 & 0.12 \\
\hline Warren & 0.12 & 0.12 & 0.12 & 0.09 \\
\hline Washington & 0.21 & 0.24 & 0.20 & 0.17 \\
\hline Wayne & 0.30 & 0.34 & 0.19 & 0.18 \\
\hline Marion County & 0.28 & 0.29 & 0.28 & 0.23 \\
\hline
\end{tabular}

Vertical Equity (Price-Relate Differential)

\begin{tabular}{l|r|r|r|r}
\hline \multirow{2}{*}{ TOWNSHIPS } & \multicolumn{2}{|c|}{ NON-MARKT } & \multicolumn{2}{c}{ MARKET } \\
\cline { 2 - 5 } Center & AY 2000 & AY 2001 & AY2004 & \multicolumn{1}{c}{ AY2005 } \\
\hline Decatur & 1.42 & 1.48 & 1.45 & 1.38 \\
\hline Franklin & 1.01 & 1.01 & 1.02 & 1.01 \\
\hline Lawrence & 1.01 & 1.01 & 1.03 & 1.02 \\
\hline Perry & 1.02 & 1.03 & 1.07 & 1.04 \\
\hline Pike & 0.98 & 0.99 & 1.02 & 1.02 \\
\hline Warren & 1.01 & 1.02 & 1.03 & 1.02 \\
\hline Washington & 1.02 & 1.02 & 1.05 & 1.04 \\
\hline Wayne & 1.07 & 1.10 & 1.06 & 1.06 \\
\hline Marion County & 1.03 & 1.05 & 1.11 & 1.08 \\
\hline
\end{tabular}


Table 3: Description of Variables in Econometric Models of Systematic Bias

\begin{tabular}{|c|c|}
\hline Variable & Description \\
\hline $\mathrm{A} / \mathrm{S}$ & $\begin{array}{l}\text { Total Gross Assessed Value (Land +Improvements)/Sale } \\
\text { Price -sales ratio in assessment year }\end{array}$ \\
\hline Sqft Unimproved Area & Total square feet of unimproved land \\
\hline $\begin{array}{l}\text { Proportion Parcel } \\
\text { Unimproved }\end{array}$ & Proportion of land that is unimproved \\
\hline Structure Age & Age of property at time of sale in years \\
\hline Square Feet & Total square feet of property at time of sale \\
\hline Proportion Non-white & $\begin{array}{l}\text { Proportion of non-white population in Census tract in } \\
\text { which the property is located (Census 2000) }\end{array}$ \\
\hline $\begin{array}{l}\text { Median Neighborhood } \\
\text { Income }\end{array}$ & $\begin{array}{l}\text { Median household income in Census tract in which the } \\
\text { property is located (Census 2000) }\end{array}$ \\
\hline Proportion Vacant & $\begin{array}{l}\text { Proportion of vacant units in Census tract in which the } \\
\text { property is located (Census 2000) }\end{array}$ \\
\hline $\begin{array}{l}\text { Proportion Built Before } \\
\text { (Cohort) }\end{array}$ & $\begin{array}{l}\text { Proportion of units in age cohorts before the cohort of } \\
\text { each observation in Census tract in which the property is } \\
\text { located (Census 2000) }\end{array}$ \\
\hline $\begin{array}{l}\text { Proportion Built After } \\
\text { (Cohort) }\end{array}$ & $\begin{array}{l}\text { Proportion of units in age cohorts after the cohort of each } \\
\text { observation in Census tract in which the property is } \\
\text { located (Census 2000) }\end{array}$ \\
\hline Frequency of Sales & $\begin{array}{l}\text { Number of sales within a } 1 \text { mile radius of each } \\
\text { observation during the previous year of sale }\end{array}$ \\
\hline Nominal Tax Rate $_{\mathrm{t}-1}$ & $\begin{array}{l}\text { Nominal tax rate of the district in which property was } \\
\text { sold prior to the base year }\end{array}$ \\
\hline Center Township & Binary variable; 1 if in Center Township, 0 else. \\
\hline Decatur Township & Binary variable; 1 if in Decatur Township, 0 else. \\
\hline Franklin Township & Binary variable; 1 if in Franklin Township, 0 else. \\
\hline Lawrence Township & Binary variable; 1 if in Lawrence Township, 0 else. \\
\hline Perry Township & Binary variable; 1 if in Perry Township, 0 else. \\
\hline Pike Township & Binary variable; 1 if in Pike Township, 0 else. \\
\hline Warren Township & Binary variable; 1 if in Warren Township, 0 else. \\
\hline Washington Township & Binary variable; 1 if in Washington Township, 0 else. \\
\hline Wayne Township & Binary variable; 1 if in the Wayne Township, 0 else. \\
\hline Year $_{t+1}$ & $\begin{array}{l}\text { Binary variable; } 1 \text { if property sold in sample secondyear } \\
\text { of assessment April-March, } 0 \text { else. }\end{array}$ \\
\hline
\end{tabular}


Table 4: Descriptive Statistics in Econometric Models of Systematic Bias

\begin{tabular}{|c|c|c|}
\hline VARIABLES & $\begin{array}{c}\text { NON- } \\
\text { MARKETN=17,036 }\end{array}$ & MARKETN=18,396 \\
\hline & $\begin{array}{c}\text { Mean } \\
\text { (St. Dev) }\end{array}$ & $\begin{array}{c}\text { Mean } \\
\text { (St. Dev) }\end{array}$ \\
\hline $\mathrm{A} / \mathrm{S}$ & $\begin{array}{r}53.11 \\
(22.26) \\
\end{array}$ & $\begin{array}{r}92.37 \\
(36.42) \\
\end{array}$ \\
\hline Sqft Unimproved Area $(10,000)$ & $\begin{array}{r}1.29 \\
(1.53) \\
\end{array}$ & $\begin{array}{r}1.31 \\
(1.73) \\
\end{array}$ \\
\hline Proportion Parcel Unimproved & $\begin{array}{l}87.05 \\
(6.12) \\
\end{array}$ & $\begin{array}{r}86.89 \\
(6.21) \\
\end{array}$ \\
\hline Structure Age & $\begin{array}{r}39.76 \\
(27.09) \\
\end{array}$ & $\begin{array}{r}40.74 \\
(28.13) \\
\end{array}$ \\
\hline Square Feet (100) & $\begin{array}{l}19.48 \\
(9.27) \\
\end{array}$ & $\begin{array}{l}20.09 \\
(9.86) \\
\end{array}$ \\
\hline Proportion Non-white & $\begin{array}{r}24.93 \\
(26.27) \\
\end{array}$ & $\begin{array}{r}23.52 \\
(25.43) \\
\end{array}$ \\
\hline Median Neighborhood Income $(\$ 1,000)$ & $\begin{array}{r}\$ 49.97 \\
(20.42) \\
\end{array}$ & $\begin{array}{r}\$ 51.23 \\
(20.66) \\
\end{array}$ \\
\hline Proportion Vacant & $\begin{array}{r}5.38 \\
(5.60) \\
\end{array}$ & $\begin{array}{r}5.14 \\
(5.36) \\
\end{array}$ \\
\hline Proportion Built Before (Cohort) & $\begin{array}{r}18.06 \\
(23.93) \\
\end{array}$ & $\begin{array}{r}21.16 \\
(26.06) \\
\end{array}$ \\
\hline Proportion Built After (Cohort) & $\begin{array}{r}26.53 \\
(25.92) \\
\end{array}$ & $\begin{array}{r}24.32 \\
(26.00) \\
\end{array}$ \\
\hline Frequency of Sales & $\begin{array}{r}228.10 \\
(119.12) \\
\end{array}$ & $\begin{array}{r}240.89 \\
(133.20) \\
\end{array}$ \\
\hline Nominal Tax Rate $_{\mathrm{t}-1}$ & $\begin{array}{r}9.04 \\
(1.02) \\
\end{array}$ & $\begin{array}{r}3.27 \\
(0.30) \\
\end{array}$ \\
\hline Center Township & $\begin{array}{r}0.15 \\
(0.36 \\
\end{array}$ & $\begin{array}{r}0.13 \\
(0.34) \\
\end{array}$ \\
\hline Decatur Township & $\begin{array}{r}0.03 \\
(0.16) \\
\end{array}$ & $\begin{array}{r}0.03 \\
(0.16) \\
\end{array}$ \\
\hline Franklin Township & $\begin{array}{r}0.05 \\
(0.21) \\
\end{array}$ & $\begin{array}{r}0.06 \\
(0.24) \\
\end{array}$ \\
\hline Lawrence Township & $\begin{array}{r}0.15 \\
(0.36) \\
\end{array}$ & $\begin{array}{r}0.14 \\
(0.35) \\
\end{array}$ \\
\hline Perry Township & $\begin{array}{r}0.10 \\
(0.30) \\
\end{array}$ & $\begin{array}{r}0.11 \\
(0.31) \\
\end{array}$ \\
\hline Pike Township & $\begin{array}{r}0.11 \\
(0.31) \\
\end{array}$ & $\begin{array}{r}0.11 \\
(0.31) \\
\end{array}$ \\
\hline Warren Township & $\begin{array}{r}0.13 \\
(0.33) \\
\end{array}$ & $\begin{array}{r}0.12 \\
(0.33) \\
\end{array}$ \\
\hline Washington Township & $\begin{array}{r}0.15 \\
(0.36) \\
\end{array}$ & $\begin{array}{r}0.16 \\
(0.37) \\
\end{array}$ \\
\hline Wayne Township & $\begin{array}{r}0.15 \\
(0.35) \\
\end{array}$ & $\begin{array}{r}0.14 \\
(0.35) \\
\end{array}$ \\
\hline Year $_{\mathrm{t}+1}$ & $\begin{array}{r}0.52 \\
(0 . .50) \\
\end{array}$ & $\begin{array}{r}0.49 \\
(0.50) \\
\end{array}$ \\
\hline
\end{tabular}


Table 5: OLS Estimates of Systematic Bias in Assessment Sales Ratio

\begin{tabular}{|c|c|c|c|}
\hline & & $\begin{array}{l}\text { NON- } \\
\text { MARKETn=17,036 }\end{array}$ & MARKETn=18,396 \\
\hline & Variables & $\begin{array}{l}\ln (\mathrm{A} / \mathrm{S}) \\
\text { Coefficient } \\
\text { (Std. Err) }\end{array}$ & $\begin{array}{l}\ln (\mathrm{A} / \mathrm{S}) \text { Coefficient } \\
\text { (Std. Err) }\end{array}$ \\
\hline \multirow{5}{*}{ 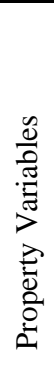 } & $\begin{array}{l}\text { SqftUnimproved Area } \\
(10,000)\end{array}$ & $\begin{array}{r}-0.00059 \\
(0.00187) \\
\end{array}$ & $\begin{array}{r}-0.01119 \\
(0.00149)^{\mathrm{a}} \\
\end{array}$ \\
\hline & $\begin{array}{l}\text { Proportion Parcel } \\
\text { Unimproved }\end{array}$ & $\begin{array}{r}0.00233 \\
(0.00063)^{\mathrm{a}} \\
\end{array}$ & $\begin{array}{r}0.00030 \\
(0.00055) \\
\end{array}$ \\
\hline & Structure Age & $\begin{array}{r}-0.00874 \\
(0.00054)^{\mathrm{a}}\end{array}$ & $\begin{array}{r}-0.00201 \\
(0.00042)^{\mathrm{a}}\end{array}$ \\
\hline & $\left(^{(S t r u c t u r e ~ A g e}\right)^{2}$ & $\begin{array}{r}0.00003 \\
(0.00001)^{\mathrm{a}} \\
\end{array}$ & $\begin{array}{r}0.000005 \\
(0.000004) \\
\end{array}$ \\
\hline & $\begin{array}{l}\text { Square Ft. Living Area } \\
(100)\end{array}$ & $\begin{array}{r}-0.00135 \\
(0.00035)^{\mathrm{a}} \\
\end{array}$ & $\begin{array}{r}-0.00202 \\
(0.00026)^{\mathrm{a}} \\
\end{array}$ \\
\hline \multirow{7}{*}{ 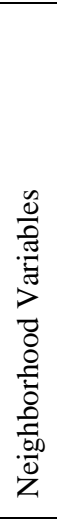 } & Proportion Nonwhite & $\begin{array}{r}0.00422 \\
(0.00016)^{\mathrm{a}}\end{array}$ & $\begin{array}{r}0.00180 \\
(0.00015)^{\mathrm{a}}\end{array}$ \\
\hline & Median Income $(1,000)$ & $\begin{array}{r}-0.00003 \\
(0.00017) \\
\end{array}$ & $\begin{array}{r}-0.00016 \\
(0.00014) \\
\end{array}$ \\
\hline & $\begin{array}{l}\text { Proportion Vacant } \\
\text { Structures }\end{array}$ & $\begin{array}{r}0.01059 \\
(0.00092)^{\mathrm{a}}\end{array}$ & $\begin{array}{r}0.00571 \\
(0.00088)^{\mathrm{a}}\end{array}$ \\
\hline & Proportion Before Cohort & $\begin{array}{r}-0.00041 \\
(0.00013)^{\mathrm{a}}\end{array}$ & $\begin{array}{r}0.00018 \\
(0.00011)^{\mathrm{a}}\end{array}$ \\
\hline & Proportion After Cohort & $\begin{array}{r}-0.00021 \\
(0.00013)^{\mathrm{c}}\end{array}$ & $\begin{array}{r}0.00029 \\
(0.00012)^{\mathrm{a}}\end{array}$ \\
\hline & Frequency of Sale & $\begin{array}{r}-0.00013 \\
(0.00003)^{\mathrm{a}}\end{array}$ & $\begin{array}{r}-0.00011 \\
(0.00002)^{\mathrm{a}} \\
\end{array}$ \\
\hline & Nominal Tax Rate $_{\mathrm{t}-1}$ & $\begin{array}{r}-0.06217 \\
(0.00391)^{\mathrm{a}} \\
\end{array}$ & $\begin{array}{r}-0.03262 \\
(0.01204)^{\mathrm{a}} \\
\end{array}$ \\
\hline \multirow{11}{*}{ 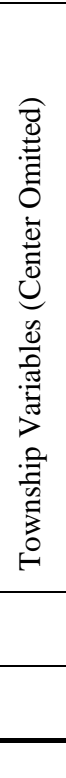 } & Decatur & $\begin{array}{r}-0.00468 \\
(0.01646)\end{array}$ & $\begin{array}{r}0.04789 \\
(0.01606)^{\mathrm{a}}\end{array}$ \\
\hline & Franklin & $\begin{array}{r}-0.03307 \\
(0.01422)^{\mathrm{b}} \\
\end{array}$ & $\begin{array}{r}0.06806 \\
(0.01474)^{\mathrm{a}} \\
\end{array}$ \\
\hline & Lawrence & $\begin{array}{r}-0.04644 \\
(0.01379)^{\mathrm{a}} \\
\end{array}$ & $\begin{array}{r}-0.05061 \\
(0.01368)^{\mathrm{a}} \\
\end{array}$ \\
\hline & Perry & $\begin{array}{r}-0.01949 \\
(0.01304) \\
\end{array}$ & $\begin{array}{r}0.01139 \\
(0.01288) \\
\end{array}$ \\
\hline & Pike & $\begin{array}{r}-0.14791 \\
(0.01477)^{\mathrm{a}} \\
\end{array}$ & $\begin{array}{r}-0.04374 \\
(0.01468)^{\mathrm{a}}\end{array}$ \\
\hline & Warren & $\begin{array}{r}-0.03563 \\
(0.01233)^{\mathrm{a}} \\
\end{array}$ & $\begin{array}{r}0.01870 \\
(0.01275) \\
\end{array}$ \\
\hline & Washington & $\begin{array}{r}-0.24925 \\
(0.01366)^{\mathrm{a}}\end{array}$ & $\begin{array}{r}-0.10742 \\
(0.01347)^{\mathrm{a}}\end{array}$ \\
\hline & Wayne & $\begin{array}{r}-0.04095 \\
(0.01416)^{\mathrm{a}}\end{array}$ & $\begin{array}{r}0.03903 \\
(0.01435)^{\mathrm{a}} \\
\end{array}$ \\
\hline & Year $_{\mathrm{t}+1}$ & $\begin{array}{r}-0.01155 \\
(0.00459)^{\mathrm{b}}\end{array}$ & $\begin{array}{r}-0.05590 \\
(0.00420)^{\mathrm{a}} \\
\end{array}$ \\
\hline & cons & $\begin{array}{r}4.52212 \\
(0.06691)^{\mathrm{a}} \\
\end{array}$ & $\begin{array}{r}4.67414 \\
(0.06601)^{\mathrm{a}} \\
\end{array}$ \\
\hline & $\overline{\mathrm{R}^{2}}$ & 0.3486 & 0.1254 \\
\hline
\end{tabular}


Table 6: Sample Mean, Median, and Percentage Differential

\begin{tabular}{l|r|r}
\hline & NON-MARKET & \multicolumn{2}{|c}{ Market } \\
\hline Mean A/S & 53.11 & 92.37 \\
\hline Median A/S & 52.20 & 86.44 \\
\hline Percentage Differential & $1.7 \%$ & $6.8 \%$ \\
\hline
\end{tabular}




\section{Figures}

Figure 1: Estimated Bias and Age of Housing Unit

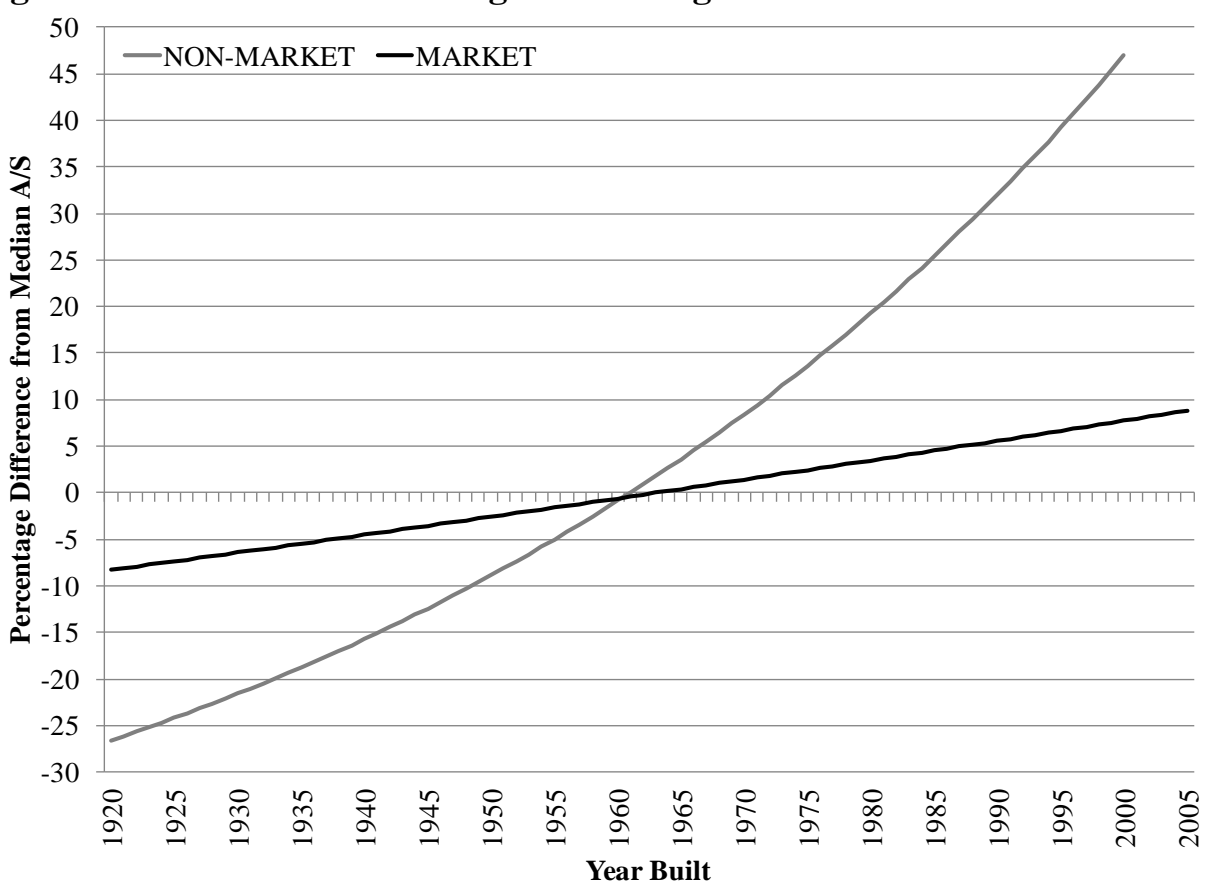

Figure 2: Estimated Bias and Housing Unit Size

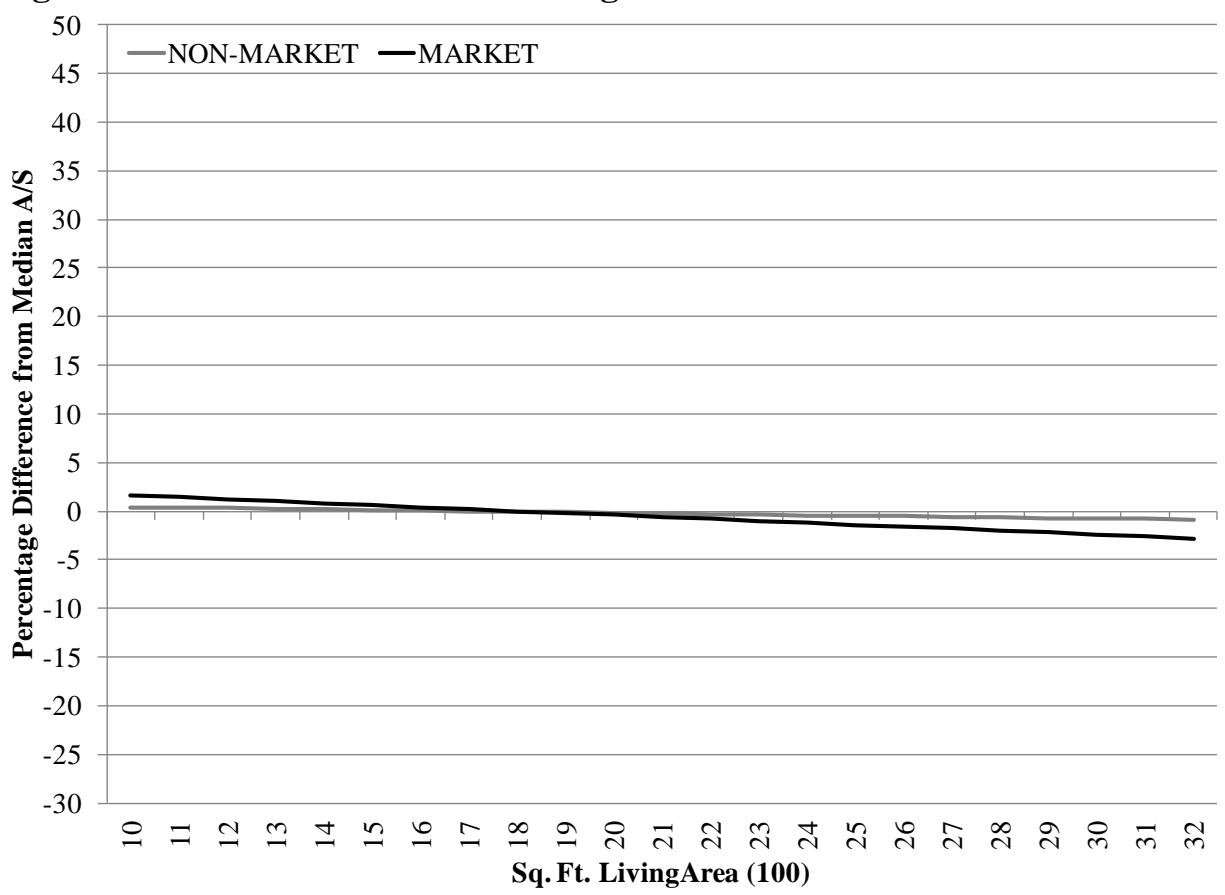


Figure 3: Estimated Bias and Sq. Ft. Unimproved Land

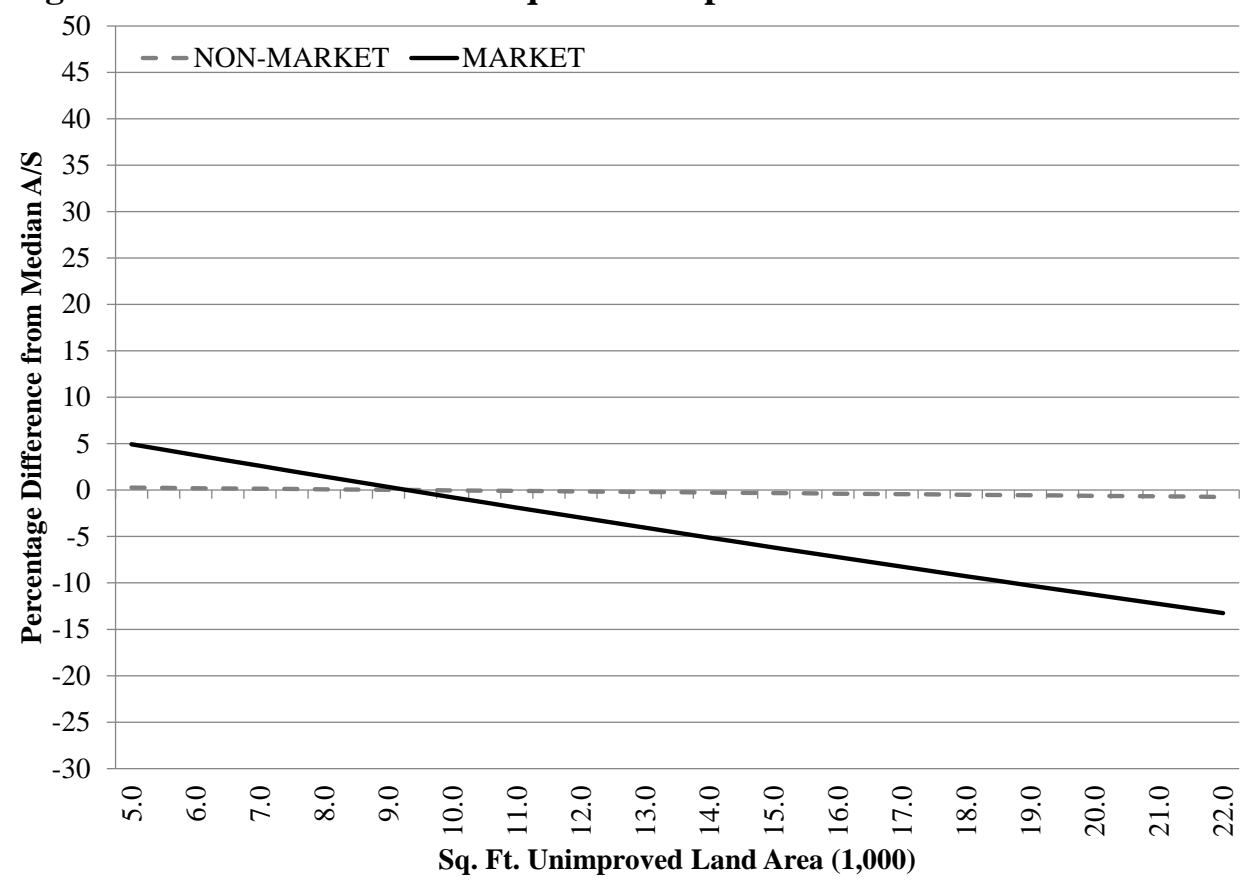

Figure 4: Estimated Bias and Proportion Unimproved Land

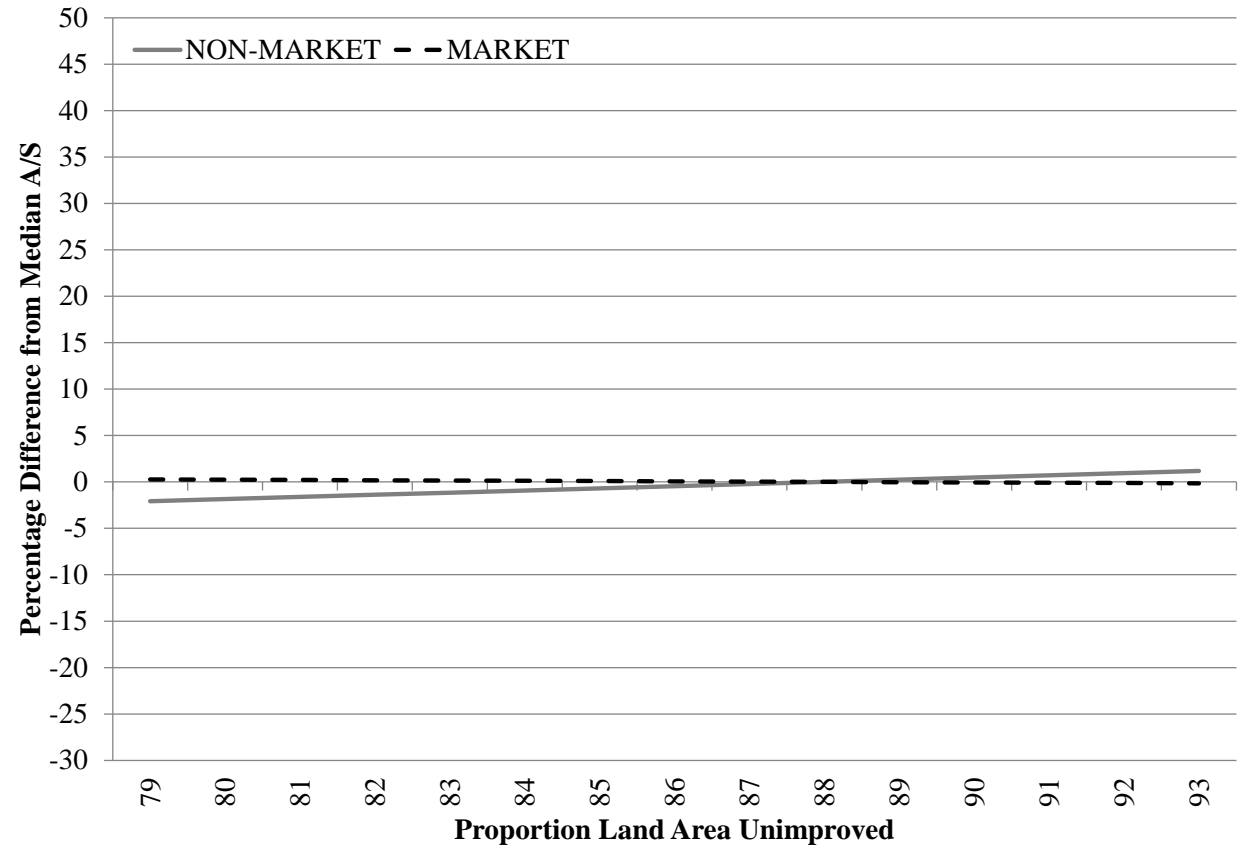


Figure 5: Estimated Bias and Non-White Population

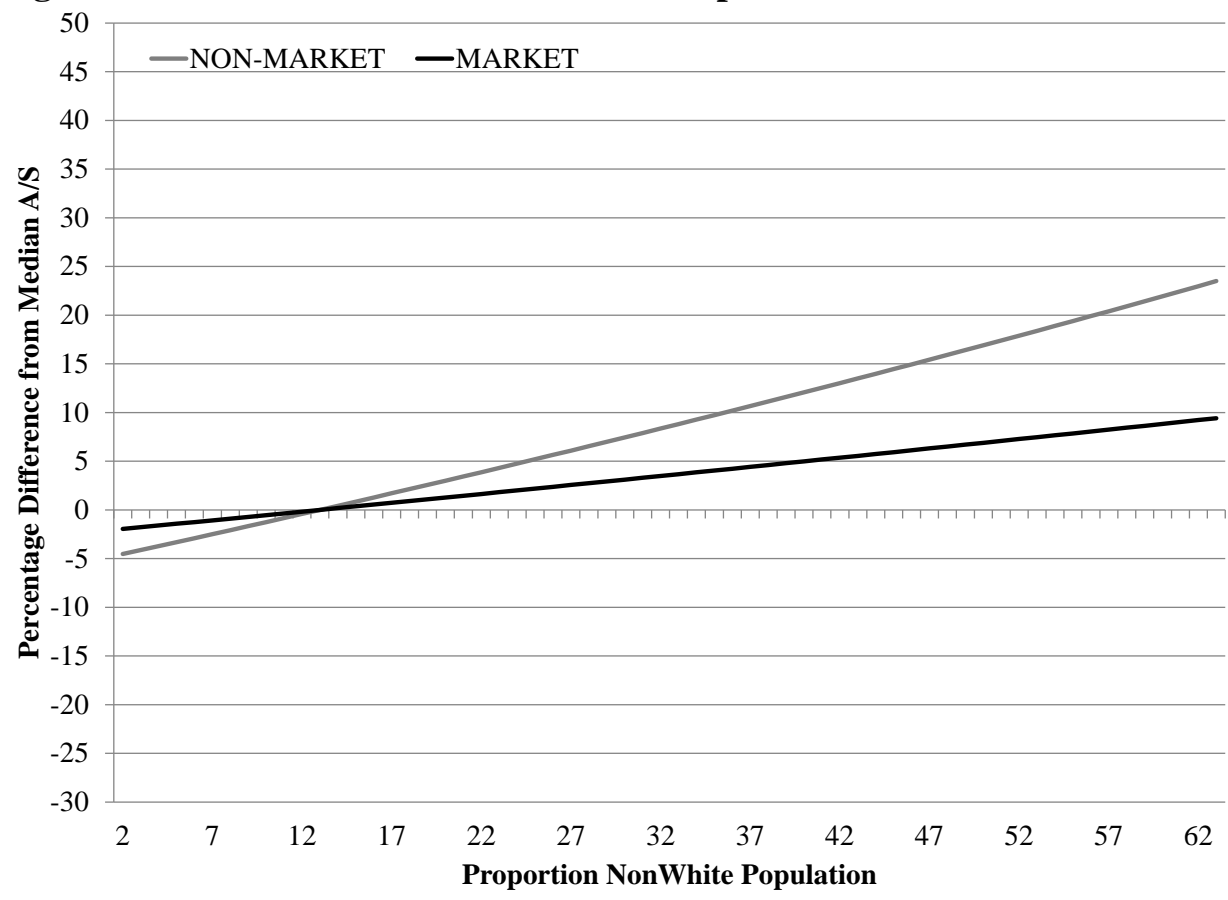

Figure 6: Estimated Bias and Vacant Units

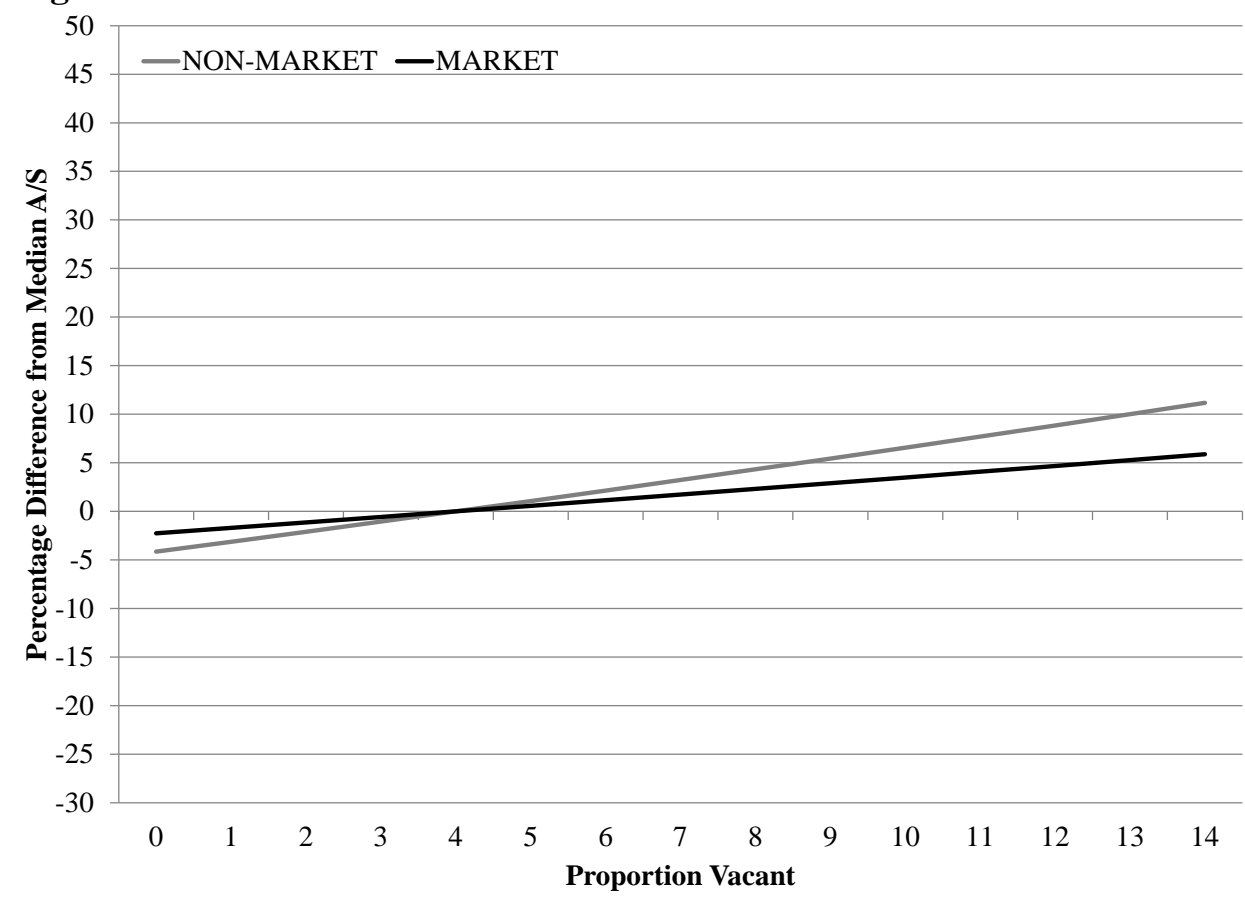

